Article

\title{
Ru(II) pyridyl-based NNN complex catalysts for (asymmetric) transfer hydrogenation of ketones at room temperature
}

\author{
DU Wangming, WANG Qingfu, YU Zhengkun* \\ Dalian Institute of Chemical Physics, Chinese Academy of Sciences, Dalian 116023, Liaoning, China
}

\section{A R T I C L E I N F O}

Article history:

Received 7 March 2013

Accepted 21 March 2013

Published 20 July 2013

Keywords:

$\mathrm{Ru}(\mathrm{II})$ complex

Asymmetric transfer hydrogenation

Chiral imidazolinyl

Benzimidazolyl

Ketone

\begin{abstract}
A B S T R A C T
$\mathrm{Ru}(\mathrm{II})$ complexes bearing pyridyl-based benzimidazolyl-imidazolinyl tridentate NNN ligands were synthesized and structurally characterized. Their molecular structure was confirmed by X-ray crystallography. These complexes demonstrated good to excellent catalytic activity in the asymmetric transfer hydrogenation of ketones at room temperature, achieving up to $99 \%$ yields and $97 \%$ ee values.
\end{abstract}

(C) 2013, Dalian Institute of Chemical Physics, Chinese Academy of Sciences. Published by Elsevier B.V. All rights reserved.

\section{Introduction}

Asymmetric syntheses aim to provide versatile strategies for direct access to chiral products and have been extensively studied and applied in organic chemistry and the pharmaceutical industry [1]. Among these, asymmetric transfer hydrogenation (ATH) catalyzed by transition metals has gradually become a reliable method for the reduction of ketones and imines [2-8]. Ruthenium complexes have proved to be the most promising catalysts for this purpose, and among the best results reported so far have been $\mathrm{Ru}(\mathrm{II})$ complexes containing a monotosylated 1,2-diamine ligand [9,10]. These have been demonstrated to be powerful catalysts for the enantioselective reduction of ketones and imines. Recently, Baratta and co-authors [11] found that 2-(aminomethyl) pyridine (ampy) accelerated the transfer hydrogenation (TH) of ketones [12-14] in $\mathrm{Ru}(\mathrm{II})$ and Os(II) complex catalysts. Very recently, Morris group $[15,16]$ reported that chiral NNPP ligands and their iron(II) complexes were effective in the ATH of ketones under mild conditions, representing a rare case of using inexpensive iron as the active metal. Although new ligands and their transition metal complexes have been established in this area [17-20], the desire for more highly active catalytic systems with better stereoselectivity and broader substrate scopes under mild conditions is still strong. We have recently documented that highly active transition metal complex catalysts could be rationally constructed by introducing a benzimidazolyl or pyrazolyl coordinating arm on a pyridyl-based ligand framework [21-30]. A series of highly active Ru(II) complexes have been obtained for the transfer hydrogenation of ketones [31,32], achieving $>99 \%$ yield and final TOFs up to $720000 \mathrm{~h}^{-1}$ at $82{ }^{\circ} \mathrm{C}$, and $99 \%$ ee and final TOFs up to 55800 $\mathrm{h}^{-1}$ at $28^{\circ} \mathrm{C}$ in $\mathrm{ATH}$ (Scheme 1).

Chiral imidazolines have been used in a number of applications in asymmetric synthesis [33], among which bidentate phosphine imidazolines have been used in the enantioselective

*Corresponding author. Tel/Fax: +86-411-84379227; E-mail: zkyu@dicp.ac.cn

This work was supported by the National Basic Research Program of China (973 Program, 2009CB825300).

DOI: 10.1016/S1872-2067(12)60583-X | http://www.sciencedirect.com/science/journal/18722067 | Chin. J. Catal., Vol. 34, No. 7, July 2013 


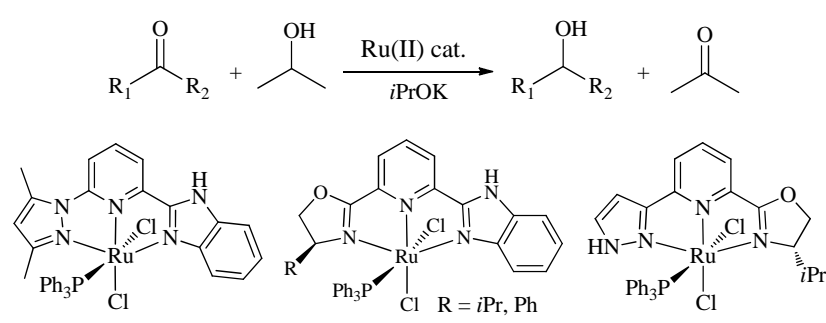

Final TOF: $720000 \mathrm{~h}^{-1}$ for TH at $82{ }^{\circ} \mathrm{C}$; $55800 \mathrm{~h}^{-1}$ with $99 \%$ ee for ATH at $28{ }^{\circ} \mathrm{C}$ [8-10]

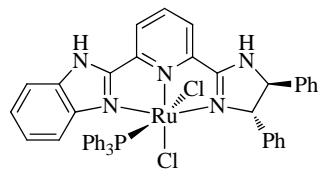

6b, this work

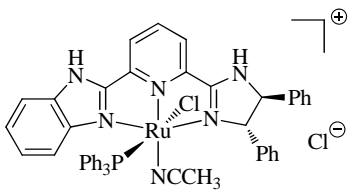

6c, this work
Scheme 1. Representative Ru(II) complexes for the asymmetric transfer hydrogenation developed in our laboratory.

hydrogenation of olefins [34] and allylic substitutions [35], tridentate benzene-bis(imidazolinyl) palladium complexes in asymmetric aza-Morita-Baylis-Hillman reactions [36] and Friedel-Crafts alkylations [37], and pyridinebisimidazoline NNN ligands in ATH [38], asymmetric epoxidation [39] and Henry reactions [40]. Herein, we report the synthesis of $\mathrm{Ru}(\mathrm{II})$ complexes bearing a tridentate NNN ligand containing benzimidazolyl and imidazolinyl moieties.

\section{Experimental}

\subsection{Materials}

6-Bromopicolinic acid, $o$-phenylenediamine, polyphosphoric acid, (+/-)-1,2-diphenylethane-1,2-diamine, (S,S)-1,2-diphenylethane-1,2-diamine, and $\mathrm{N}$-methylimidazole were commercially available. $\mathrm{K}_{4}\left[\mathrm{Fe}(\mathrm{CN})_{6}\right]$ was dried at $60{ }^{\circ} \mathrm{C}$ for $6 \mathrm{~h}$ under reduced pressure prior to use. Acetonitrile, 2-propanol, and dichloromethane were dried by refluxing over $\mathrm{CaH}_{2}$, and toluene and diethyl ether were dried by refluxing over sodium with benzophenone as indicator before being distilled. Other chemicals were used as received.

\subsection{Preparation of NNN ligands and Ru(II)-NNN complexes}

Heating a mixture of 6-bromopicolinic acid (1) and $o$-phenylenediamine in polyphosphoric acid afforded the intermediate compound $\mathbf{2}$ in $45 \%$ yield (Scheme 2). Copper(I)-catalyzed cyanation of $\mathbf{2}$ with $\mathrm{K}_{4}\left[\mathrm{Fe}(\mathrm{CN})_{6}\right]$ gave $\mathbf{3}$. Treatment of $\mathbf{3}$ with $\mathrm{NaOMe}$ in refluxing methanol formed the imidate 4, which was then condensed with the racemic diamine in $\mathrm{CH}_{2} \mathrm{Cl}_{2}$ to give the racemic tridentate NNN ligand 5a. Refluxing ligand 5a with $\mathrm{RuCl}_{2}\left(\mathrm{PPh}_{3}\right)_{3}$ in toluene produced the $\mathrm{Ru}(\mathrm{II})-\mathrm{NNN}$ complex $\mathbf{6 a}$ as a red-brown powder in $82 \%$ yield.

In a similar preparation to $\mathbf{6 a}$, chiral ligand $\mathbf{5 b}$ was reacted with $\mathrm{RuCl}_{2}\left(\mathrm{PPh}_{3}\right)_{3}$ to afford the chiral $\mathrm{Ru}(\mathrm{II})$ complex $\mathbf{6 b}$ (Scheme 3). Unexpectedly, the neutral complex $\mathbf{6 b}$ was transformed into the ionic complex $\mathbf{6 c}$ during recrystallization from
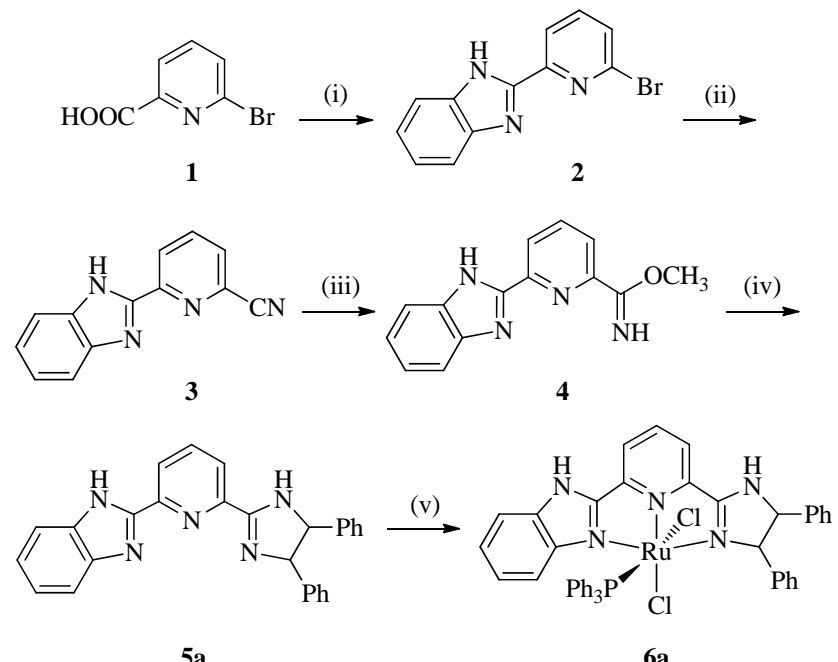

Scheme 2. Synthesis of ligand $\mathbf{5 a}$ and $\mathrm{Ru}(\mathrm{II})$ complex $\mathbf{6 a}$. (i) $o$-phenylenediamine, polyphosphoric acid, $160{ }^{\circ} \mathrm{C}, 4 \mathrm{~h}, 45 \%$; (ii) CuI, $\mathrm{K}_{4}\left[\mathrm{Fe}(\mathrm{CN})_{6}\right], \mathrm{N}$-methylimidazole, $160^{\circ} \mathrm{C}, 16 \mathrm{~h}, 61 \%$; (iii) $\mathrm{Na}, \mathrm{MeOH}, 65$ ${ }^{\circ} \mathrm{C}, 14 \mathrm{~h}, 85 \%$; (iv) (+/-)-1,2-diphenylethane-1,2-diamine, $\mathrm{CH}_{2} \mathrm{Cl}_{2}, 40{ }^{\circ} \mathrm{C}$, 12 h, 90\%; (v) $\mathrm{RuCl}_{2}\left(\mathrm{PPh}_{3}\right)_{3}$, toluene, $110{ }^{\circ} \mathrm{C}, 3 \mathrm{~h}, 82 \%$.

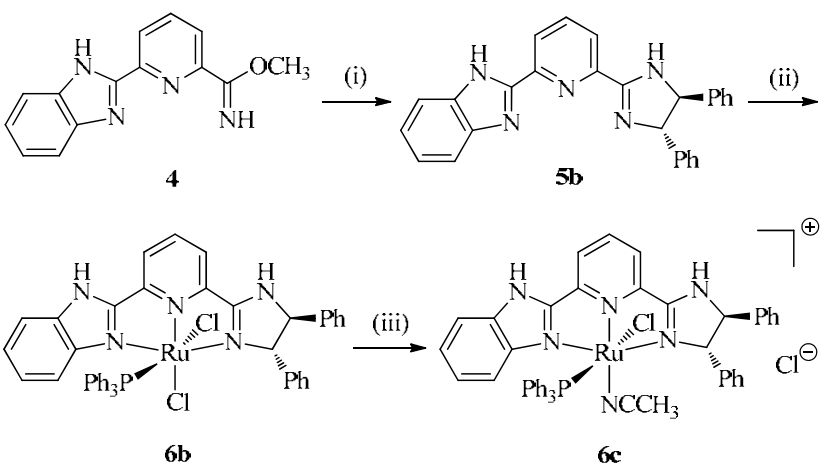

Scheme 3. Synthesis of chiral ligand $\mathbf{5 b}$ and complexes $\mathbf{6 b}$ and $\mathbf{6 c}$. (i) $(S, S)$-1,2-diphenylethane-1,2-diamine, $\mathrm{CH}_{2} \mathrm{Cl}_{2}, 40{ }^{\circ} \mathrm{C}, 12 \mathrm{~h}, 90 \%$; (ii) $\mathrm{RuCl}_{2}\left(\mathrm{PPh}_{3}\right)_{3}$, toluene, $110{ }^{\circ} \mathrm{C}, 3 \mathrm{~h}, 82 \%$; (iii) Recrystallization from $\mathrm{CH}_{3} \mathrm{CN} / \mathrm{Et}_{2} \mathrm{O}(1 / 3, V / V)$.

$\mathrm{CH}_{3} \mathrm{CN}-\mathrm{Et}_{2} \mathrm{O}$. In $\mathbf{6 c}$, an acetonitrile molecule replaced coordinated $\mathrm{Cl}$ ion at the metal center.

\subsection{Procedure for transfer hydrogenation of ketones}

A typical procedure for the catalytic asymmetric transfer hydrogenation of ketones was as follows. Under a nitrogen atmosphere, a mixture of $2 \mathrm{mmol}$ ketone, $18.6 \mathrm{ml} i$-PrOH, and 1 $\mathrm{ml}$ of the chiral catalyst solution containing $4 \mu \mathrm{mol}$ of the $\mathrm{Ru}(\mathrm{II})$ complex in $i$-PrOH was stirred at $28{ }^{\circ} \mathrm{C}$ for $10 \mathrm{~min}$. A $0.4 \mathrm{ml}$ of $0.1 \mathrm{~mol} / \mathrm{L} i$-PrOK solution in $i$-PrOH was then introduced to initiate the reaction. During the reaction, $0.1 \mathrm{ml}$ of the reaction mixture was sampled and immediately diluted with $0.5 \mathrm{ml}$ $i$-PrOH pre-cooled at $0{ }^{\circ} \mathrm{C}$ for GC analysis on a chiral $\beta$-DEX 225 (supelco) column. After the reaction was complete, the remaining reaction mixture was condensed under reduced pressure and purified by silica gel column chromatography to afford the corresponding alcohol product. This was then identified by comparison with the authentic sample by ${ }^{1} \mathrm{H}$ NMR and/or GC analysis. 


\section{Results and discussion}

\subsection{Structural characterization of compounds $\mathbf{5}$ and $\mathbf{6}$}

All new compounds were characterized by NMR spectroscopy and either HRMS or elemental analysis, giving results that are consistent with their proposed compositions. The benzimidazolyl and imidazolinyl N-H functionalities in complexes 6a and $\mathbf{6 b}$ showed a singlet resonance at $\delta=15.03$ and 9.40 in the ${ }^{1} \mathrm{H}$ NMR spectra, respectively, revealing the presence of the N-H moieties. The molecular structure of complex $\mathbf{6 c}$ was confirmed by X-ray crystallography (Fig. 1), and the two distinctive N-H moieties remained unchanged. In the solid state, the ruthenium atom in $\mathbf{6 c}$ is coordinated by the tridentate NNN ligand $\mathbf{5 b}$, one $\mathrm{PPh}_{3}$ ligand, one $\mathrm{CH}_{3} \mathrm{CN}$ molecule, and one $\mathrm{Cl}$ ion. $\mathrm{The} \mathrm{PPh}_{3}$ ligand is trans to the bonded $\mathrm{Cl}$ ion and anti to one of the phenyl groups of the chiral imidazolinyl moiety. This reduces the steric interactions in the complex. The $\mathrm{P}-\mathrm{Ru}-\mathrm{N}$ angles are in the range of $89.9^{\circ}-96.6^{\circ}$, and $\mathrm{P}-\mathrm{Ru}-\mathrm{Cl}(1)$ and $\mathrm{N}(3)-\mathrm{Ru}-\mathrm{N}(6)$ angles are $178.6^{\circ}$ and $170.2^{\circ}$, respectively, suggesting that the $\mathrm{Ru}$ atom is situated at the center of a distorted bipyramidal environment with the $\mathrm{CH}_{3} \mathrm{CN}$ molecule and $\mathrm{N}(3)$ atom of the pyridyl backbone trans to each other.

\subsection{Transfer hydrogenation of ketones}

Following the procedure previously reported from our laboratory [21-32], complex 6a was tested as a catalyst for the transfer hydrogenation of acetophenone in the presence of $i$-PrOK. To our surprise, 6a exhibited excellent catalytic activity for the reduction of acetophenone in 2-propanol even at room temperature $\left(28^{\circ} \mathrm{C}\right)$. With a loading of $0.2 \%$ (molar fraction) $\mathbf{6 a}$ as catalyst, acetophenone was converted to 1-phenylethanol in $96 \%$ yield within 5 min, giving a final TOF value of $5760 \mathrm{~h}^{-1}$ (entry 1, Table 1). This catalytic system was applied to the transfer hydrogenation of a variety of ketones, including substituted acetophenones, aliphatic cyclic and acyclic ketones, generating the corresponding alcohols as the sole products. In most of the cases, the ketone substrates reached $>98 \%$ conversions within $10 \mathrm{~min}$ with final TOF values up to $59400 \mathrm{~h}^{-1}$ within $30 \mathrm{~s}$ (entry 13), demonstrating a rare example of a highly active transition metal complex catalyst for the transfer hydrogenation of ketones [29]. Acetophenones containing an

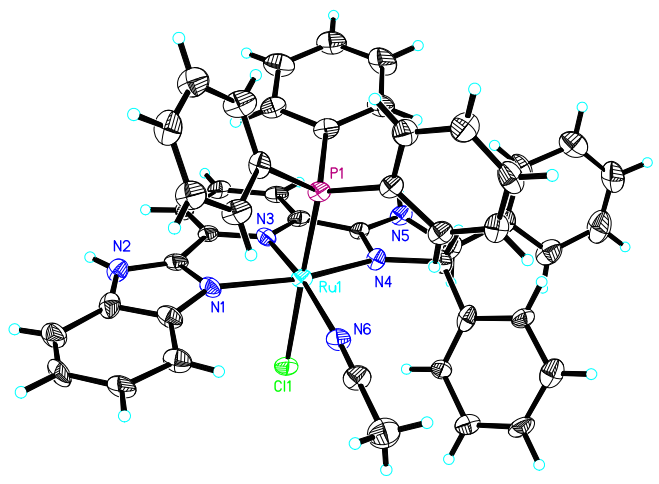

Fig. 1. Molecular structure of complex $6 c$.
Table 1

Transfer hydrogenation of ketones.

\begin{tabular}{|c|c|c|c|c|}
\hline Entry & Ketone & Time (min) & Yield a (\%) & Final TOF $\left(\mathrm{h}^{-1}\right)$ \\
\hline 1 & & 5 & 96 & 5760 \\
\hline 2 & & 10 & 97 & 2910 \\
\hline 3 & & 5 & 96 & 5760 \\
\hline 4 & & 2 & 98 & 14700 \\
\hline 5 & & 1 & 99 & 29700 \\
\hline 6 & & 1 & 97 & 29100 \\
\hline 7 & & 1 & 98 & 29400 \\
\hline 8 & & 2 & 98 & 14700 \\
\hline 9 & & 1 & 99 & 29700 \\
\hline 10 & & 1 & 99 & 29700 \\
\hline 11 & & 2 & 98 & 14700 \\
\hline 12 & & 2 & 98 & 14700 \\
\hline 13 & & 0.5 & 98 & 59400 \\
\hline 14 & & 2 & 97 & 14500 \\
\hline 15 & & 5 & 93 & 2790 \\
\hline 16 & & 10 & 98 & 2940 \\
\hline 17 & & 20 & 86 & 2580 \\
\hline 18 & & 2 & 98 & 14700 \\
\hline 19 & & 5 & 97 & 5820 \\
\hline 20 & & 90 & 80 & 267 \\
\hline 21 & & 10 & 98 & 2940 \\
\hline 22 & & 5 & 97 & 5820 \\
\hline
\end{tabular}

Reaction conditions: ketone $2.0 \mathrm{mmol}(0.1 \mathrm{~mol} / \mathrm{L}$ in $20 \mathrm{ml} i$-PrOH$)$; ketone $/ i$-PrOK $/ 6 \mathbf{6 a}=500 / 20 / 1 ; p\left(\mathrm{~N}_{2}\right)=0.1 \mathrm{MPa} ; 28^{\circ} \mathrm{C}$.

a Determined by GC analysis.

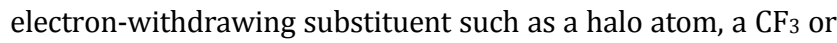
methyl group reacted the fastest (entries 3-15), while electron-donating methoxy group-bearing acetophenones required longer reaction times (entries 16 and 17). To our delight, all the fluoro- and trifluoromethyl-bearing acetophenones could be smoothly reduced to the desired alcohols (entries 9-13). Other ketones such as benzophenone, 2-acetylnaphthalene, and aliphatic ketones also exhibited high reactivity (entries 18, 19, 21, and 22), but indanone only showed moderate reactivity (entry 20). 


\subsection{Asymmetric transfer hydrogenation of ketones}

The chiral Ru(II) complex $\mathbf{6 b}$ was then employed as the catalyst for the ATH of acetophenone under the same conditions as shown in Table 1 . With a $0.2 \%$ loading of $\mathbf{6 b}$ as catalyst, acetophenone was reduced to the corresponding chiral alcohol at room temperature $\left(28{ }^{\circ} \mathrm{C}\right)$, achieving $96 \%$ yield and $85 \%$ ee within 5 min (entry 1, Table 2), and $\mathbf{6 b}$ exhibited the same catalytic activity as the racemic catalyst $\mathbf{6 a}$ (entry 1, Table 1). Increasing the reaction temperature accelerated the reaction, but the enantiomer excesses decreased from $85 \%$ to $26 \%$ (entries $3-5$, Table 2). A base effect was observed that improved the product enantioselectivity. Lowering the base loading to 10 equivalents of the catalyst enhanced the enantioselectivity to $90 \%$ ee (entry 6, Table 2). Under the same conditions, chiral complex $\mathbf{6 c}$ exhibited catalytic activity inferior to $\mathbf{6 b}$ (entry 7 Table 2).

Under the optimized reaction conditions, a variety of ketones were tested as substrates to explore the generality of the protocol. As shown in Table 3, acetophenones with both electron-withdrawing and -donating substituents were tolerated to give the corresponding chiral alcohol products in very high yield. Acetophenone, propiophenone, and ortho-substituted acetophenones could be reduced to the chiral alcohols within 2-10 min, reaching $97 \%$ ee with final TOFs up to $14850 \mathrm{~h}^{-1}$ (entries 1-5, Table 3). The asymmetric reduction of meta-, pa$r a-$, and 2'-methyl-substituted acetophenones was also accomplished, affording less enantioselective alcohol products (74\%-84\% ee, entries 6-11, Table 3). A strong steric effect resulted in the highest product enantioselectivity. 2'-Trifluoromethyl-substituted acetophenone was reduced to the corresponding alcohol in $97 \%$ ee (entry 3, Table 3). As the bulkiness of the substituents decreased from bromo to chloro, the resultant enantioselectivity decreased from $95 \%$ to $93 \%$ (entries 4 and 5, Table 3). We have previously shown that a benzimidazolyl N-H in a ligand can accelerate the TH and ATH of ketones [28-30], and an imidazolinyl N-H functionality has also been reported as improving the enantioselectivity in ATH [38]. In

Table 2

Screening of conditions for asymmetric transfer hydrogenation of ketones catalyzed by $\mathbf{6 b}$.

\begin{tabular}{|c|c|c|c|c|c|}
\hline Entry & $\begin{array}{l}\text { Catalyst } \\
(\mathrm{mol} \%)\end{array}$ & $\begin{array}{c}\text { Temperature } \\
\left({ }^{\circ} \mathrm{C}\right) \\
\end{array}$ & $\begin{array}{l}\text { Time } \\
\text { (min) }\end{array}$ & $\begin{array}{c}\text { Yield }^{a} \\
(\%)\end{array}$ & $\begin{array}{l}e^{a} \\
(\%)\end{array}$ \\
\hline 1 & 0.2 & 28 & 5 & 96 & $85(S)$ \\
\hline 2 & 0.3 & 28 & 5 & 96 & $85(S)$ \\
\hline 3 & 0.2 & 40 & 2 & 96 & $83(S)$ \\
\hline 4 & 0.1 & 60 & 1 & 95 & $26(S)$ \\
\hline 5 & 0.02 & 80 & 2 & 97 & $33(S)$ \\
\hline $6^{b}$ & 0.2 & 28 & 5 & 95 & $90(S)$ \\
\hline $7 \mathrm{c}$ & 0.2 & 28 & 5 & 76 & $68(S)$ \\
\hline
\end{tabular}

Reaction conditions: acetophenone $2.0 \mathrm{mmol}(0.1 \mathrm{~mol} / \mathrm{L}$ in $20 \mathrm{~m}$ $i$-PrOH); $i$-PrOK $/ 6 \mathbf{b}$ (or 6c) $=20 / 1 ; p\left(\mathrm{~N}_{2}\right)=0.1 \mathrm{MPa}$.

a Determined by GC analysis on a chiral column $\beta$ DEX 225 , and absolute configuration was determined by comparing optical rotations with literature values. ${ }^{\mathrm{b}} \boldsymbol{i}$-PrOK$/ \mathbf{6 b}=10 / 1 .{ }^{\mathrm{c}} \mathbf{6} \mathbf{c}$ as catalyst.
Table 3

Asymmetric transfer hydrogenation of ketones catalyzed by $\mathbf{6 b}$.

\begin{tabular}{|c|c|c|c|c|c|}
\hline Entry & Ketone & $\begin{array}{l}\text { Time } \\
\text { (min) }\end{array}$ & $\begin{array}{c}\text { Yield }^{a} \\
(\%)\end{array}$ & $\begin{array}{l}e^{a} \\
(\%)\end{array}$ & $\begin{array}{c}\begin{array}{c}\text { Final TOF } \\
\left(\mathrm{h}^{-1}\right)\end{array} \\
\end{array}$ \\
\hline 1 & & 5 & 95 & 90 & 5400 \\
\hline 2 & & 10 & 97 & 90 & 2910 \\
\hline 3 & & 5 & 96 & 97 & 5880 \\
\hline 4 & & 2 & 99 & 95 & 14850 \\
\hline 5 & & 10 & 96 & 93 & 2880 \\
\hline 6 & & 5 & 98 & 84 & 5880 \\
\hline 7 & & 2 & 98 & 74 & 14700 \\
\hline 8 & & 5 & 96 & 77 & 5760 \\
\hline 9 & & 5 & 98 & 75 & 5880 \\
\hline 10 & & 5 & 97 & 77 & 5820 \\
\hline 11 & & 5 & 95 & 74 & 5400 \\
\hline
\end{tabular}

Reaction conditions: ketone $2.0 \mathrm{mmol}(0.1 \mathrm{~mol} / \mathrm{L}$ in $20 \mathrm{ml} i$-PrOH $)$; ketone $/ i-\mathrm{PrOK} / \mathbf{6 b}=500 / 10 / 1 ; p\left(\mathrm{~N}_{2}\right)=0.1 \mathrm{MPa} ; 28^{\circ} \mathrm{C}$.

a The conversion and ee were determined by GC analysis on a chiral column $\beta$ DEX 225. All the major secondary alcohols had the $S$ configuration. Absolute configuration was determined by comparing optical rotations with literature values.

our case, the combination of the two $\mathrm{N}-\mathrm{H}$ functionalities may provide the complex catalysts with high catalytic activity and good selectivity for ATH of ketones under mild conditions.

\section{Conclusions}

Pyridyl-based benzimidazolyl-imidazolinyl tridentate NNN ligands and their $\mathrm{Ru}(\mathrm{II})$ complexes were synthesized and structurally characterized. These complex catalysts feature two heterocyclic N-H functionalities and exhibit excellent catalytic activity and selectivity in the asymmetric transfer hydrogenation of ketones under mild conditions.

\section{References}

[1] Jacobsen E N, Pfaltz A, Yamamoto H. Comprehensive Asymmetric Catalysis I-III. Berlin: Springer-Verlag, 1999. 199

[2] Moore C M, Szymczak N K. Chem Commun, 2013, 49: 400

[3] Sorribes I, Wienhöer G, Vicent C, Junge K, Llusar R, Beller M. Angew Chem, Int Ed, 2012, 51: 7794

[4] Steward K M, Gentry E C, Johnson J S. J Am Chem Soc, 2012, 134: 7329

[5] Vázquez-Villa H, Reber S, Ariger M A, Carreira E M. Angew Chem, Int Ed, 2011, 50: 8979

[6] Alonso F, Riente P, Yus M. Acc Chem Res, 2011, 44: 379

[7] Malacea R, Poli R, Manoury E. Coord Chem Rev, 2010, 254: 729 


\title{
Graphical Abstract
}

Chin. J. Catal., 2013, 34: 1373-1377 doi: 10.1016/S1872-2067(12)60583-X

Ru(II) pyridyl-based NNN complex catalysts for (asymmetric) transfer hydrogenation of ketones at room temperature

DU Wangming, WANG Qingfu, YU Zhengkun*

Dalian Institute of Chemical Physics, Chinese Academy of Sciences

$\mathrm{Ru}(\mathrm{II})$ complexes bearing pyridyl-based benzimidazolyl-imidazolinyl tridentate NNN ligands exhibited excellent catalytic activity and selectivity in the asymmetric transfer hydrogenation of ketones at room temperature.

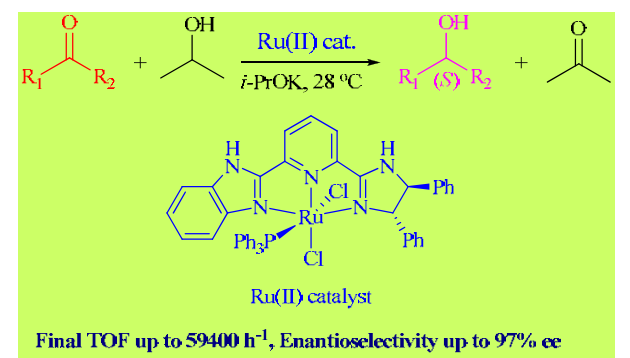

[8] Bartók M. Chem Rev, 2010, 110: 1663

[9] Ikariya T, Blacker A J. Acc Chem Res, 2007, 40: 1300

[10] Noyori R, Hashiguchi S. Acc Chem Res, 1997, 30: 97

[11] Baratta W, Herdtweck E, Siega K, Toniutti M, Rigo P. Organometallics, 2005, 24: 1660

[12] Baratta W, Ballico M, Chelucci G, Siega K, Rigo P. Angew Chem, Int Ed, 2008, 47: 4362

[13] Baratta W, Chelucci G, Herdtweck E, Magnolia S, Siega K, Rigo P. Angew Chem, Int Ed, 2007, 46: 7651

[14] Baratta W, Chelucci G, Gladiali S, Siega K, Toniutti M, Zanette M, Zangrando E, Rigo P. Angew Chem, Int Ed, 2005, 44: 6124

[15] Mikhailine A A, Maishan M I, Lough A J, Morris R H. J Am Chem Soc, 2012, 134: 12266

[16] Sonnenberg J F, Coombs N, Dube P A, Morris R H. J Am Chem Soc, 2012, 134: 5893

[17] Touge T, Hakamata T, Nara H, Kobayashi T, Sayo N, Saito T, Kayaki Y, Ikariya T. J Am Chem Soc, 2011, 133: 14960

[18] Díaz-Valenzuela M B, Phillips S D, France M B, Gunn M E, Clarke M L. Chem EurJ, 2009, 15: 1227

[19] Lundgren R J, Rankin M A, McDonald R, Schatte G, Stradiotto M. Angew Chem, Int Ed, 2007, 46: 4732

[20] Hayes A M, Morris D J, Clarkson G J, Wills M. J Am Chem Soc, 2005, 127: 7318

[21] Du W M, Wang L D, Wu P, Yu Z K. Chem Eur J, 2012, 18: 11550

[22] Zhao M, Yu Z K, Yan S G, Li Y.J Organomet Chem, 2009, 694: 3068
[23] Zeng F L, Yu Z K. Organometallics, 2008, 27: 6025

[24] Yu Z K, Zeng F L, Sun X J, Deng H X, Dong J H, Chen J Z, Wang H M, Pei C X.J Organomet Chem, 2007, 692: 2306

[25] Zeng F L, Yu Z K. J Org Chem, 2006, 71: 5274

[26] Deng H X, Yu Z K, Dong J H, Wu S Z. Organometallics, 2005, 24: 4110

[27] Jin W W, Wang L D, Yu Z K. Organometallics, 2012, 31: 5664

[28] Zeng F L, Yu Z K. Organometallics, 2009, 28: 1855

[29] Zhao M, Yu Z K, Yan S G, Li Y. Tetrahedron Lett, 2009, 50: 4624

[30] Zeng F L, Yu Z K. Organometallics, 2008, 27: 2898

[31] Ye W J, Zhao M, Yu Z K. Chem Eur J, 2012, 18: 10843

[32] Ye W J, Zhao M, Du W M, Jiang Q B, Wu K K, Wu P, Yu Z K. Chem Eur J, 2011, 17: 4737

[33] Liu H, Du D M. Adv Synth Catal, 2009, 351: 489

[34] Menges F, Neuburger M, Pfaltz A. Org Lett, 2002, 4: 4713

[35] Mei L Y, Yuan Z L, Shi M. Organometallics, 2011, 30: 6466

[36] Hyodo K, Nakamura S, Shibata N. Angew Chem, Int Ed, 2012, 51:10337

[37] Wu L Y, Hao X Q, Xu Y X, Jia M Q, Wang Y N, Gong J F, Song M P. Organometallics, 2009, 28: 3369

[38] Enthaler S, Hagemann B, Bhor S, Anilkumar G, Tse M K, Bitterlich B, Junge K, Erre G, Beller M. Adv Synth Catal, 2007, 349: 853

[39] Bhor S, Anilkumar G, Tse M K, Klawonn M, Dobler C, Bitterlich B, Grotevendt A, Beller M. Org Lett, 2005, 7: 3393

[40] Ma K Y, You J S. Chem Eur J, 2007, 13: 1863

\section{钌(II)-吡啶基NNN配合物催化酮的室温(不对称)氢转移反应}

\author{
杜旺明, 王清福, 余正坤 ${ }^{*}$ \\ 中国科学院大连化学物理研究所, 辽宁大连 116023
}

摘要: 合成了一种基于吡啶骨架含有苯并咪唑和手性咪唑啉基团的三齿NNN配体及其二价钌(II)配合物,通过核磁共振波谱学和 X射线单晶晶体结构测定确认了钉(II)配合物的分子结构. 这些配合物在室温下催化酮的氢转移反应,表现出了优异的催化活性, 收率和ee值最高分别可达 $99 \%$ 和 $97 \%$.

关键词: 钉(II)配合物; 不对称氢转移; 手性咪唑啉; 苯并咪唑; 酮

收稿日期: 2013-03-07. 接受日期: 2013-03-21. 出版日期: 2013-07-20.

*通讯联系人. 电话/传真: (0411)84379227; 电子信箱: zkyu@dicp.ac.cn

基金来源：国家重点基础研究发展计划(973计划, 2009CB825300).

本文的英文电子版由Elsevier出版社在ScienceDirect上出版(http://www.sciencedirect.com/science/journal/18722067). 